\title{
Large Mammals from the Plio-Pleistocene of Kashmir Intermontane Basin, India, with Reference to their Status in Magnetic Polarity Time Scale
}

\author{
Bahadur Singh Kotlia *)
}

\begin{abstract}
Pliocene, Pleistocene, intramontane basin, Karewa-Formation, magnetostratigraphy, fossil localities,
Hippomorpha, Equus sivalensis, Elephantidae, Elephas hysudricus, Canidae, Canis vitastensis, teeths, Ruminantia, Cervus punjabensis, antlers, biometry, paleoenvironment, range, stratigraphic boundary

India, Kashmir, Himalayas
\end{abstract}

\begin{abstract}
The larger mammalian fossils (Equus, Elephas, Cervus and Canis) being described from the Plio-Pleistocene Karewa deposits of Kashmir Valley, India, were recovered from the sections already dated by paleomagnetism. Based on these data, the occurrence of Equus and Cervus is dated to about 2.0 Ma. Elephas and Canis are documented only from the Brunhes epoch. The stratigraphic occurrence of these genera is correlated with other known biochronological sequences of subcontinent, and discussed in connection with the Plio-Pleistocene boundary in North India.
\end{abstract}

[Die Großsäuger aus dem Plio-Pleistozän des intermontanen Kashmir-Beckens, Indien, unter Berücksichtigung ihrer Stellung in der paläomagnetischen Zeitskala]

Kurzfassung: Reste von Großsäugern (Equus, Elephas, Cervus und Canis) aus der plio-pleistozänen Karewa-Formation des Kashmir-Beckens in NW-Indien werden beschrieben. $\mathrm{Da}$ die Fossilien aus paläomagnetisch datierten Schichten stammen, kann hier erstmals eine zeitliche Korrelation für das Auftreten der Großsäuger für das Kashmir-Becken gegeben werden. Equus und Cervus erscheinen erstmals vor etwa 2.0 Mio. Jahren, während Elephas und Canis erst in der Brunhes-Epoche belegt sind. Das Auftreten dieser Gattungen wird mit anderen bekannten biochronologischen Sequenzen des Subkontinentes verglichen und kurz auf die Grenzziehung zwischen Plio- und Pleistozän in Nordindien eingegangen.

\section{Introduction}

The Kashmir Valley, developed during the Late Cenozoic Era under different tectonic regimes, occupies the depression formed by the bifurcation of the Great

*) Authors address: Dr. B. S. KotLia, Institut für Paläontologie, Nussallee-8, D-5300 Bonn-1, West Germany.
Himalayan Range whose southern arm is known as the Pir Panjal Range and the northern arm as the Main Himalayan Range. In between the complexly folded and faulted mountain ramparts lies the Karewa intermontane basin which has accumulated above $1000 \mathrm{~m}$ of the Plio-Pleistocene synorogenic sediments comprising mudstone-sandstone-gravel succession (BURBANK \& JOHNSON 1982; KOTLIA 1985a; KUSUMGAR et al. 1986). The rise of the Pir Panjal Range was responsible for impounding the primaeval drainage and giving rise to a vast Karewa lake (SINGH 1982, BHATT 1983). As Pir Panjal continued to rise, the Karewa lake shrank and shifted towards the Himalayan Range. The heterogenous assemblage of lacustrine and glaciofluvial sediments (about $1000 \mathrm{~m}$ thick Lower Karewas), the lacustrine deposits (about $100 \mathrm{~m}$ thick Upper Karewas) and aeolian deposits (about $25 \mathrm{~m}$ thick loess deposits) has been accumulated in form of plateau-like terraces, called the "Karewas". The Karewa sedimentation had commenced by about $4.0 \mathrm{Ma}$ ago (BURBANK \& JOHNSON 1982, 1983; KUSUMGAR et al. 1985, 1986; AGRawal et al. 1987).

The first reference of mammalian fossils was given by De Terra \& PATERSON (1939) and followed by BADAM (1968), TeWARI \& KaCHROO (1977), KotLIa et al. (1982) and SAHNI \& KotLIA (1985). The genera collected or listed by them are Bos, Sus, Felis, Elephas, Equus, Rhinoceros and Sivatherium. While initiating and then carrying out in detail the palaeontological studies in the Karewas, Kotlia (1985a, 1987a, 1989) made collection of mega and microvertebrate fossils with their stratigraphic occurrence in a composite litho-stratigraphic column. In addition to taxonomy, this paper also discusses the stratigraphic occurrence of various fossils in terms of absolute chronology. 


\section{Geologie}

The Plio-Pleistocene Karewa deposits are commonly divided into two lithologic units, the Lower Karewa Formation (Lower Karewas) and Upper Karewa Formation (Upper Karewas). Lower Karewa deposits, in general, are gently inclined and better exposed on the Pir Panjal flank and have an unconformable contact with overlying nearly horizontal Upper Karewas which are better exposed on the Himalayan flank. The geological map of the area is shown in Fig. 1. The best exposed Lower Karewa sections are along River Rembiara between Dubjan and Krachipatra, and along River Romushi between Ichhagoz and Romu. Well exposed Upper Karewa sections are at Sombur and Burzahom. The Lower Karewas are characterised by mudstones, unconsolidated sandstones, lignite layers, and conglomerate horizons. Upper Karewas are laminated claystones, sandstones and some conglomeratic layers but without lignites. The Karewas, as a whole, are capped by loess deposits associated with dark humic layers (palaeosols).

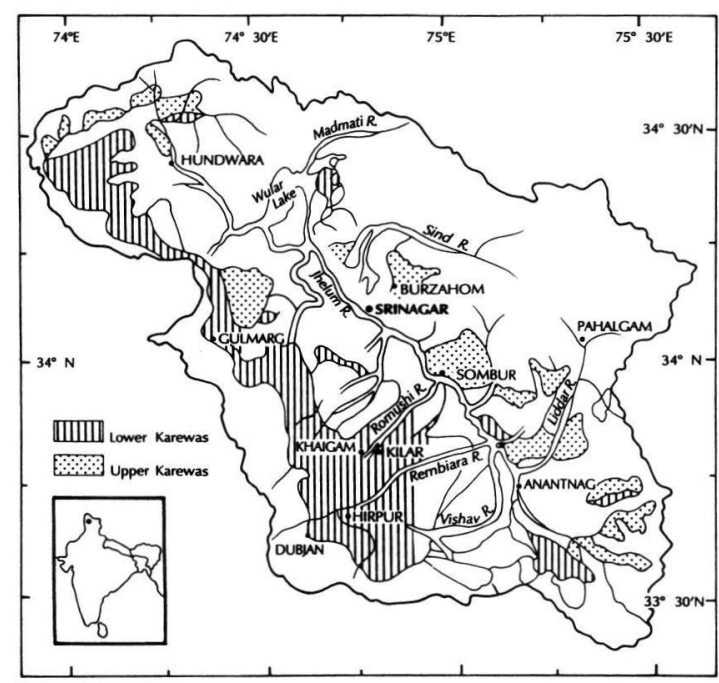

Fig. 1: Geological map of Kashmir basin showing distribution of Lower and Upper Karewas as well as the localities.

Abb. 1: Geologische Karte des Kashmir-Beckens (Indien), mit den Fundorten sowie der Verteilung der unteren und oberen Karewa-Formation.

Measured sections are shown in Fig. 2. Sediments exposed at Dubjan, Hirpur and Krachipatra localities are exposed along River Rembiara near Hirpur village, about $67 \mathrm{~km}$ SW of Stinagar. They are described together in Hirpur section, the type section for lower part of the Lower Karewas. Ichhagoz and Romu deposits, forming upper part of Lower Karewas are measured along River Romushi and described as Romushi section. Kilar section, about $60 \mathrm{~km} \mathrm{SW}$ of Srinagar is exposed along Birnai Nala, a tributary of River Romushi. All above mentioned sections are measured on the Pir Panjal flank. Sombur section, about $18 \mathrm{~km}$ SE of Srinagar, and Burzahom section, about $12 \mathrm{~km} \mathrm{NE}$ of Srinagar are represented by the Upper Karewa Formation and measured on the Himalayan flank.

\section{Biochronology}

Till about 1980 and before the application of physical dating techniques to the Kashmir deposits, the Karewas have been interpreted as being of Pleistocene (DE TERRA \& PATERSON 1939; VISHNU-MitTRE 1964), of the Late Pliocene to much of the Pleistocene (MIDDLEMISS 1924; WADIA 1951; BHATT 1975), and of Late Miocene to Pleistocene age (ROY 1975). Based on the preliminary magnetostratigraphic data, KUSUMGAR (1980) indicated that the basal part of the Karewas encompassed the Gilbert magnetic epoch. BURBANK \& JOHNSON $(1982,1983)$ and KUSUMGAR et al. (1986) developed a new chronology of the Karewas through the use of magnetic polarity stratigraphy and fission track dating of volcanic ashes and correlated various Karea sub-sections. The dates are shown in Fig. 2. With more available data, AGRAWAL et al. (1987) dated the lower part of the Karewas (Hirpur section) to 3.4-2.0 Ma, the middle part (Romushi section) to $2.4-0.2 \mathrm{Ma}$, the upper part to $<0.73 \mathrm{Ma}$, and the loess sequence to $<200 \mathrm{Ka}$. In this work, the magnetic stratigraphy is taken from KUSUMGAR et al. (1986).

Fig. 2 shows the biochronology of megavertebrate fossils. Only in-situ specimens are used for taxonomic description as well as for biochronology. The base of the Karewas extends to the Gilbert magnetic epoch, about 3.8 Ma. The Romushi and Hirpur sections are correlated based on the earlier results mentioned above. Kilar section is lateral extension of a part of the Romushi section and both are correlated by a prominent conglomeratic bed which has been physically traced from Kilar to Aglar (Romushi). Sombur section falls well within the Brunhes chron (KUSUMGAR 1980), therefore, is younger than $730 \mathrm{Ka}$. The horizon located at Burzahom is stratigraphically $20 \mathrm{~m}$ below the loess deposit. Since the loess had started depositing in Kashmir Valley at about $200 \mathrm{Ka}$ ago (AGRAWAL et al. 1987), the underlying Karea sediments at Burzahom are savely considered to be slightly older than $200 \mathrm{Ka}$.

The first horizon, yielding the remains of Hexapotodon is at Dubjan locality, stratigraphically about $24 \mathrm{~m}$ above the base of Hirpur section. The specimen was 


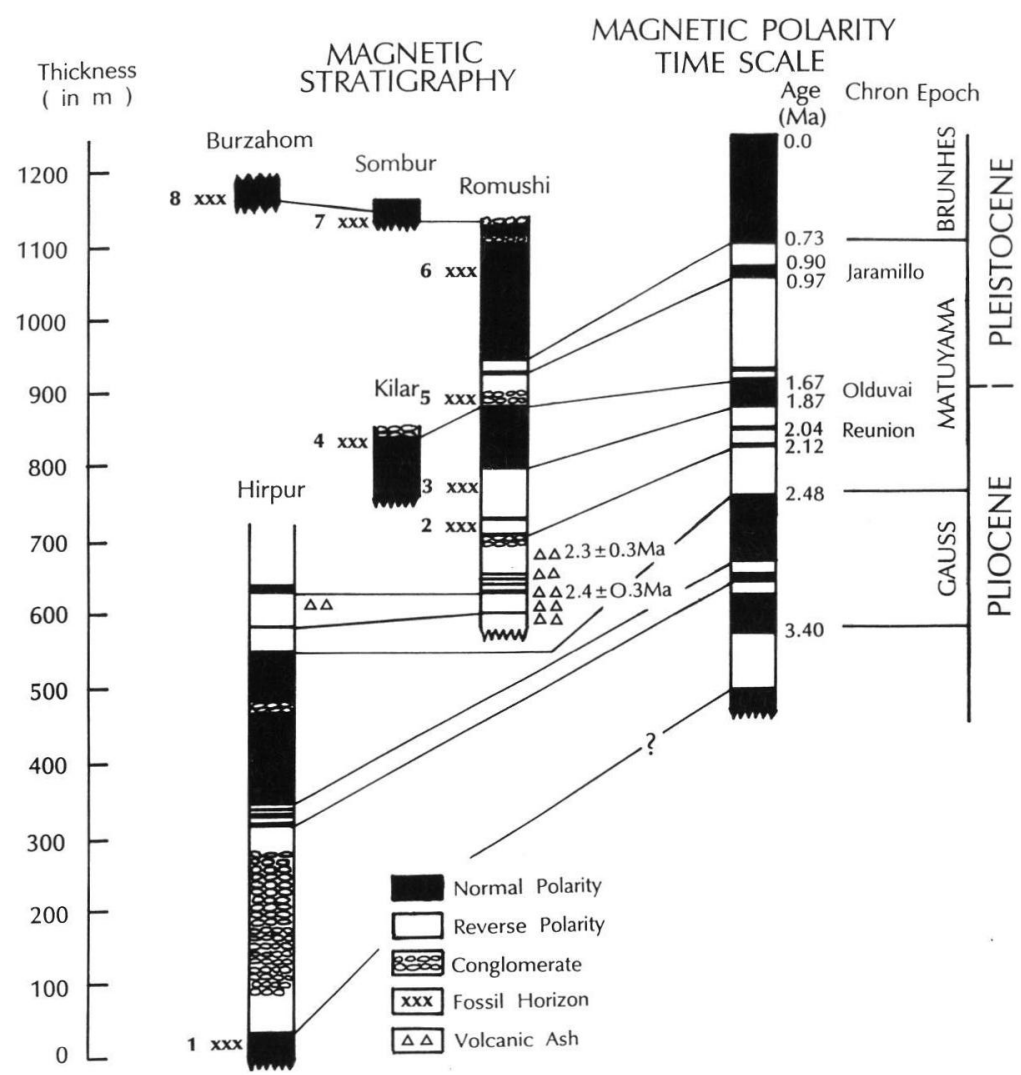

Fig. 2: Correlation of vertebrate horizons and geomagnetic data in the Karewa formation (modified after KUSUMGAR et al. (1986). Base of Karewas extends to about 3.8 Ma.

Various sub-sections are correlated as described in text. In addition two layers of volcanic ash have been dated absolutely one of $2.4 \pm 0.3 \mathrm{Ma}$ given by BURBANK \& JOHNSON (1983), and other of $2.3 \pm 0.3 \mathrm{Ma}$ given by KUSUMGAR et al. (1986). The fossil horizons (1-8) yielded: 1, Hexaprotodon; 2, Cervus punjabiensis; 3, Equus sivalensis; 4, E. sivalensis; 5 , Cervus sivalensis; 6, Elephas hysudricus; 7, E. hysudricus; 8, Canis vitastensis.

Abb. 2: Korrelation zwischen den Fundhorizonten der Wirbeltiere und den paläomagnetischen Daten in der Karawa-Formation (verändert nach Kusumgar et al. 1986). Die Basis der Karewa-Formation liegt bei 3.8 Ma. Die Zuordnung der einzelnen Schichtglieder erfolgt im Text. Zusätzlich liegen für zwei Lagen mit vulkanischer Asche absolute Daten vor. Die eine wird von BURBANK \& JoHNSON (1983) auf 2,4 \pm 0.3 Ma datiert,

die zweite von Kusumgar et al. (1986) auf 2,3 $\pm 0,3 \mathrm{Ma}$. Die Fossilhorizonte (1-8) erbrachten:

1: Hexaprotodon; 2: Cervus punjabiensis; 3 und 4: Equus sivalensis; 5: Cervus sivalensis; 6: Elephas hysudricus; 7: E. hysudricus; 8: Canis vitastensis.

collected from the sediments showing normal polarity, probably belonging to Cochiti magnetic event. The 2nd horizon (dated to Reunion magnetic event), yielding the remains of Cervus is located near village Ichhagoz, about $30 \mathrm{~m}$ above the basal conglomerate of Romushi section (see Fig. 2). Based on few antler fragments, this material was originally identified by KOTLIA et al. (1982) as Cervus sivalensis. However, with recovery of complete and well preserved antlers, it is well identified as Cervus punjabiensis. About 70 $\mathrm{m}$ above this sand bed, is located 3rd horizon which has yielded the molars of Equus sivalensis alongwith numerous bone fragments. This horizon is located both in Romushi and Shaliganga (Husgund) sections. The 4th horizon with an age of about $1.6 \mathrm{Ma}$ is represented by upper part of the Kilar section and has yielded Equus sivalensis. Antlers of Cervus sivalensis are collected from the second conglomerate horizon of the Romushi section, considered here as 5th horizon and dated to about $1.6 \mathrm{Ma}$. The records of Elephas bysudricus are from the Brunhes chron (younger than $730 \mathrm{Ka}$ ), represented by 6th horizon. Among Upper Karewa localities, Sombur section has yielded Elephas bysudricus. This is described as 7 th horizon, dated to $<730 \mathrm{Ka}$. The 8th horizon, located at Burzahom has yielded Canis vitastensis remains. 
Several Karewa lithologies were observed to be richly fossiliferous. The main are: dark mudstones interbedded with medium to coarse grained sandstones with gastropod shells as first and 4th horizons; lensoid, loose and current bedded sand beds as 2nd and 3rd horizons; conglomerates with sandstone and mudstone lenses as 5th horizon; medium grained unconsolidated huge sandstones interstratified with siltstones and greyish to yellowish patches of claystones as 6 th and 7 th hoirzons.

\section{Systematic palaeontology}

The large mammals, described by the earlier workers have been referred from villages without reference to measured sections. Thus, there is no information available of the exact location within the stratigraphic succession. However, one explanation for earlier finds could be that most of the fossils mentioned by DE TERRA \& PATERSON (1939) and BADAM $(1968,1972)$ are from the Upper Karewas which are, in general, younger than $730 \mathrm{Ka}$ in age.

The fossils described and illustrated herein were obtained in situ and keyed to a master litholog. The specimens are housed in the Museum of vertebrate palaeontological Laboratory (VPL) of the Centre of Advanced Study in Geology, Chandigarh. Several specimens collected from the surface lag deposits are not taken into consideration as their exact horizons could not be ruled out. The main emphasis is given to the morphological description of Equus, Elephas and Cervus. New species of Canis have earlier been described by KOTLIA (1987b). Since more work on Hexaprotodon material is under progress, description is not given here. While describing equid material, dental terminology of AZZAROLI (1979) is used. Dental terminology of cervids and morphological analysis of antlers are used as given by BROWN (1926) and POCOCK (1933).

\subsection{Perissodactyla}

\subsubsection{Equus sivalensis FALCONER \& CAUTLEY 1849} (Figs. 3-7)

1849 Equus sivalensis FALCONER \& CAUTLEY, Fauna Antiqua Sivalensis: pl. 81, Figs. 1-4; pl. 82, Figs. $1-6$.

1935 Equus namadicus FALCONER \& CAUTLEY, Colbert, Trans. Amer. Phil. Soc. 26, 160-161.

1982 Equus sivalensis FALCONER \& CAUTLEY, Azzaroli, Paleont. Ital. 72, 1-79.

Lectotype: British Museum No. 16160, a cranium.
Cotypes: British Museum Nos. 17227, posterior portion of cranium; M 2626, left maxilla; M 2698, premaxilla und symphysis; 22107 , portion of right ramus; 22108, portion of mandible.

Referred material: VPL/B 2071, lower right premolar; VPL/B 2072, lower left molar; VPL/B 2073, lower left molar; VPL/B 2074, lower left premolar; VPL/B 2075, upper right molar. Many other postcranial fragments and vertebrae.

Locality and horizon: Romushi section, 3rd horizon (Fig. 2). VPL/B 2071 and 2074 are from Husgund (Raithan) locality in Shaliganga section, well correlated with 3rd horizon of Romushi section, and has been used as the same by KUSUMGAR et al. (1986).

\subsubsection{Description of new material}

Lower premolar (VPL/B 2074). Protoconid is smaller than hypoconid and the outer wall of hypoconid is situated slightly anteriorly compared to protoconid. The metaconid is rounded and slightly bigger than metastylid which is compressed lingually. The entoconid broadly opens into a triangular hypoconulid. The metaflexid is wider with its anterior portion compressed labiolingually. The entoflexid is compressed along the anteroposterior length of tooth. Both metaflexid and entoflexid are filled with cement and open lingually through narrow openings. The ectoflexid is deep and pointed; it is separated from the anterior margin of entoflexid and posterior margin of metaflexid. The metaconid and metastylid form the characteristic double knot of equids.

Lower molar (VPL/B 2072): Protoconid and hypoconid are well developed, hypoconid being larger than protoconid. The anterior extremity of protoconid runs along lingual side of tooth, giving rise the anterior margin of metaflexid. The hypoconulid is triangular in shape. Metaconid is rounded cusp and narrowly opens into metastylid. The metaflexid is slightly curved and compressed anterolabially. Entoflexid is wider than metaflexid and is having mild crenulations on the outer wall. Linguaflexid is exactly V shaped with lingual sinus open and deep. Ectoflexid is somewhat angular, deep and narrowly separated from posterior side.

Lower molar (VPL/B 2073): The anterior part of protoconid, the hypoconid, and a part of entoconid are broken in the specimen. The anterior extremity of protoconid runs along anterior side of the tooth and has a thin enamel. The metaconid is larger than metastylid. The posterior wall of metaflexid is directed downward and outer wall of entoconid is crenulated. 


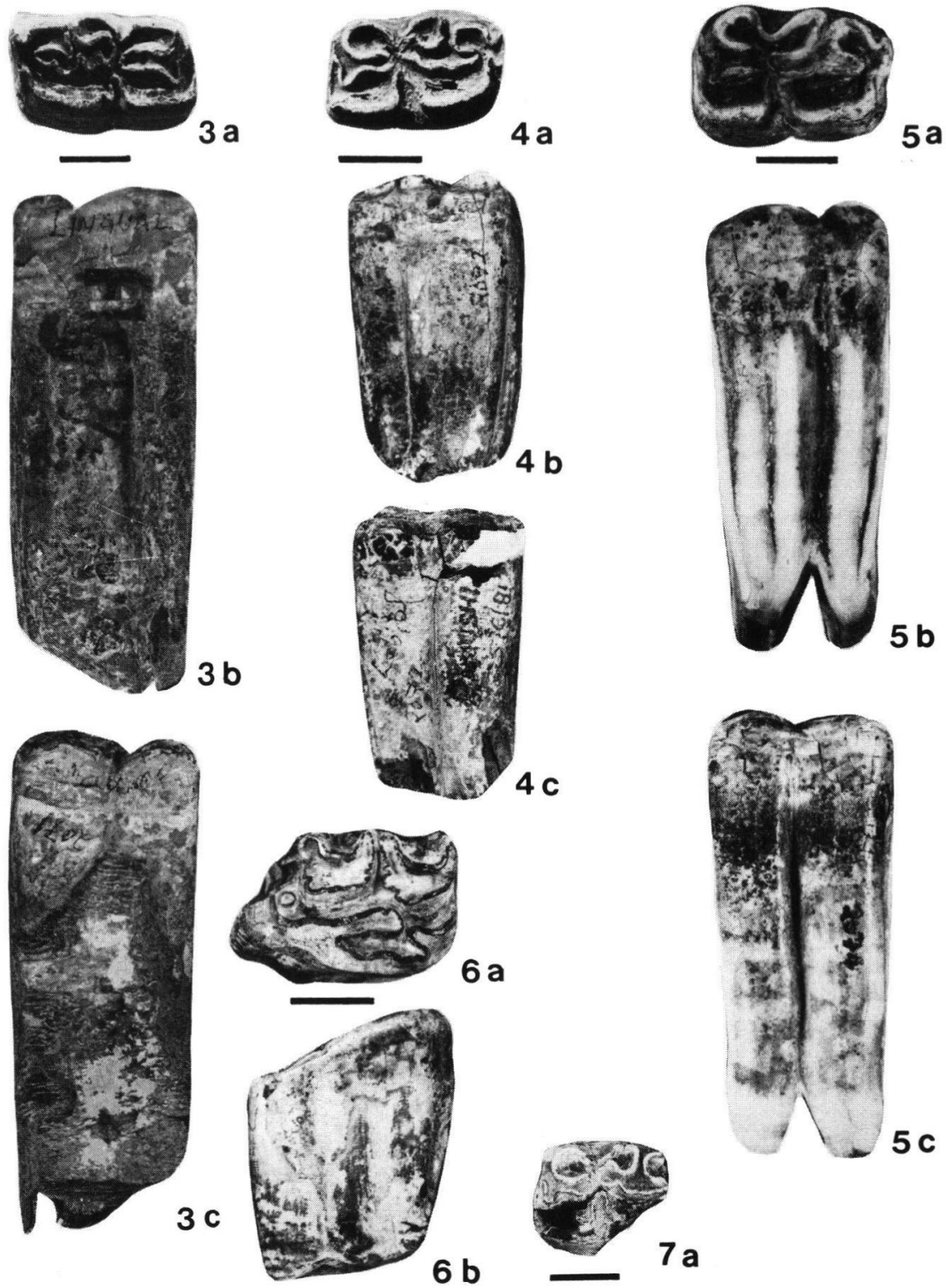

Fig. 3-7:

Molars of Equus sivalensis from Romushi (4, VPL/B 2072; 6, VPL/B 2075; 7, VPL/B 2073) and Raithan sections (3, VPL/B 2071; 5 VPL/B 2074). $a$, occlusal; b, lingual; and c, labial views. All belong to the third horizon. Bar represents $1 \mathrm{~cm}$.

Abb. 3-7: Molaren von Equus sivalensis aus Romushi und Raithan. a: Kauflächen, b: Lingualansicht und c: Labialansicht. Maßstab $=1 \mathrm{~cm}$.
Lower premolar (VPL/B 2071): Protoconid is narrower than hypoconid with the posterior wall extending into the crown. The hypoconid is broad and separated from entoconid by hypoconulid which is slightly curved and directed posterolingually. The metaconid is compressed lingually and is larger than rounded metastylid. Ectoflexid is narrow, V shaped and set apart from posterior margin of metaflexid. The posterior end of metaflexid and anterior end of entoflexid lie close to each other and the dentine in between them is fairly well developed. The entoflexid is more expanded posteriorly having crenulations on outer wall.
Upper molar (VPL/B 2075): The prefossette is compressed labially having a number of crenulations on the posterior wall. The postfossette is wider than prefossette and possesses crenulations on enamel border. The posterior margin of prefossette and anterior margin of postfossette lie opposite to each other and extend upto mesostyle. There are two re-entrants, one on posterolingual margin of prefossette and other on posterolingual border of postfossette. The outer margin of postfossette reaches upto mesostyle, thus producing a weakly developed metacone. The Plicaballin is slightly curved. Protocone is elongated and oriented anteroposteriorly. 
Table 1: Measurements (in $\mathrm{mm}$ ) of Equus sivalensis specimens
Premolar
L. molar
L. molar
Premolar
U. molar

\begin{tabular}{llllll} 
VPL/B number & 2071 & 2072 & 2073 & 2074 & 2075 \\
Length & 29.0 & 22.0 & 21.0 & 25.0 & 27.5 \\
Width & 14.9 & 12.5 & 11.0 & 15.5 & 20.5 \\
\hline
\end{tabular}

Remarks: So far, four species of Equus have been described from India, viz., E. sivalensis, E. namadicus, E. palaeonus and E. cautleyi. E. namadicus is of large size whereas $E$. sivalensis is relatively small. In $E$. namadicus, protocones of the premolars and molars are much longer than in $E$. sivalensis. Further, E. sivalensis is older in age than E. namadicus. E. cautleyi has larger size of mandibular rami than that of $E$. sivalensis which also differs with present day E. caballus in possessing smaller protocones. Clearly distinguishable $E$. sivalensis and $E$. cautleyi remains are from Pinjor Formation and E. namadicus from Narmada alluvium (KHAN 1972).

\subsection{Artiodactyla}

4.2.1. Cervus punjabiensis BROWN 1926 (Figs. 8-9)

1926 Cervus punjabiensis BROWN, Amer. Mus. Novitat. 243

1935 Cervus punjabiensis BROwN, Colbert, Trans. Amer. Phil. Soc. 26, 320

1954 Cervus punjabiensis Brown, Azzaroli, Proc. Linn. Soc. 165

Holotype: Amer. Mus. No. 19911, an incomplete skull with antlers.

Referred material: VPL/B 3002, upper left molar; VPL/B 3003, right antler. Numerous broken parts of the antlers.

Locality and horizon: Romushi section, 2nd horizon in Fig. 2.

\subsubsection{Description of new material}

Upper molar (VPL/B 3002): Protocone has a broad and rounded inner surface with an outer wall exactly parallel to the anteroposterior axis of crown. On lingual side, protocone projects more lingually than hypocone, inner surface of which is slightly angular, sloping from lingual to labial side. Between protocone and hypocone, there is small and slender accessory tubercule which is placed in the valley considerably further in than the base of protocone and hypocone. Paracone shows two costae, one median and other at anterior border, the latter produced into an angle on anterolabial side. The costae on both paracone and metacone run perpendicularly to the base of crown but the outer surface of metacone becomes slightly wider as it approaches the base of crown. The maximum length and width of the specimen are 22.0 and $23.0 \mathrm{~mm}$ respectively.

Right antler with pedicle (VPL/B 3003): The light brownish coloured antler supported on a short and circular pedicle is moderately smooth in outline. The palmate central portion is rounded consisting of a heavily fossilised burr with an irregular margin. There is an anterior tine (brow tine) projecting

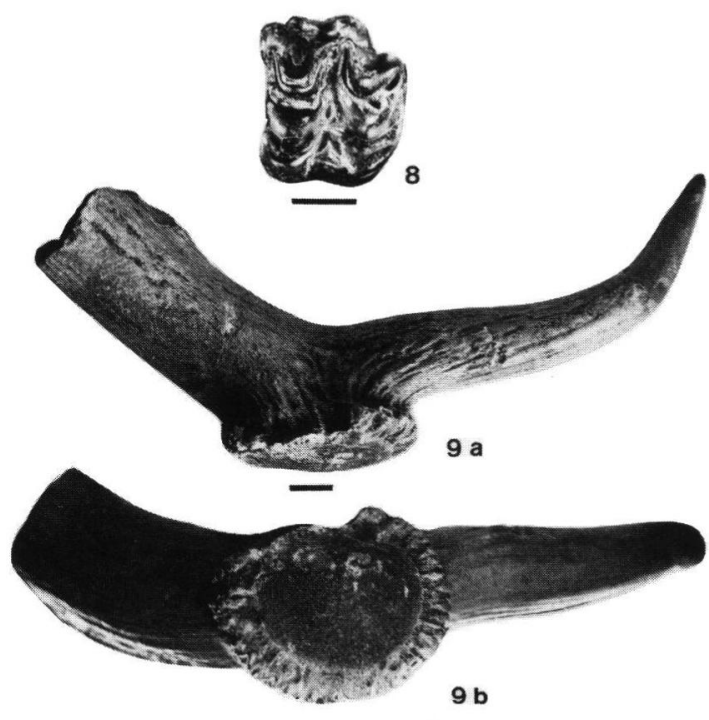

Fig. 8-9: Upper molar and antler of Cervus punjabiensis (8, VPL/B 3002; 9, VPL/B 3003). 8, occlusal; 9a, lateral; $9 \mathrm{~b}$, frontal view. Bar represents $2 \mathrm{~cm}$.

Abb. 8-9: Oberer Molar und Geweihfragment von Cervus punjabiensis. 8: Kauflächenbild; 9a: Mesialansicht; 9 b: Blick auf die Rose. Maßstab $=2 \mathrm{~cm}$. 
forward then slightly inward and finally towards the posterior parts of palmate portion of antler. Posteriorly, the palmate portion of antler is continued back in beam with a prominent median axis and a rear tine. The rear tine of terminal fork which forms the continuation of beam is long and wider. The posterior tine (beam) seems to have a small ridge along median axis above which the present specimen is broken. The brow tine is circular in cross section with a pointed tip at end. The antler is divergent, the brow tine making an obtuse angle (147 degree) with the beam.

The longitudinal grooves run parallel to median axis of the brow tine. The grooves are more prominent near palmate central portion, less prominent in middle part and are almost absent near the pointed termination of brow tine, thus giving rise a smooth surface to the tine. The beam consists of a few longitudinal grooves running parallel to median axis and they are nearly absent on lateral sides and therefore the beam looks smoother than brow tine. The beam is triangular to circular in outline.

Remarks: The molars of Cervus punjabiensis are distinguished from other species: by the presence of costae and grooves; by outer surfaces of lobes slightly narrower at the base than crown; by presence of small cingulum on anterior side; by presence of a bilobed groove on poorly developed accessory column (Sensu, LYDEKKER 1876) together with presence of smooth enamel. The lack of parallelism of outer surface of paracone and metacone on the molars is the character shared by $C$. punjabiensis and $C$. latidens but the latter strongly differs from the former in having the large accessory column and strongly developed posterolabial angle. C. triplidens differs from C. punjabiensis in an unusually large accessory column, rugose enamel and more prominent costae. C. simplidens resembles $C$. punjabiensis by the squareness of crown, a smaller obliquity of external halves of protocone and metacone but differs in having rugose enamel and better developed accessory column. The character of having transverse axis of two lobes nearly perpendicular to longitudinal axis of crown is shared by $C$. punjabiensis and $C$. sivalensis but the peculiarity of having high elongated crown on upper molars, rugose and folded enamel and a strong anterointernal fold distinguishes C. sivalensis from $C$. punjabiensis. The molars of $C$. punjabiensis can also be distinguished from those of C. simplicidens by enfold enamel and by a rudimentary accessory column on first molar.

The antlers of $C$. punjabiensis are differentiated from those of Rucervus simplicidens (AZZAROLI 1954) by their comparatively smooth and longitudinally grooved surface, and from those of $C$. sivalensis in having a moderately smooth outline. Beam of the
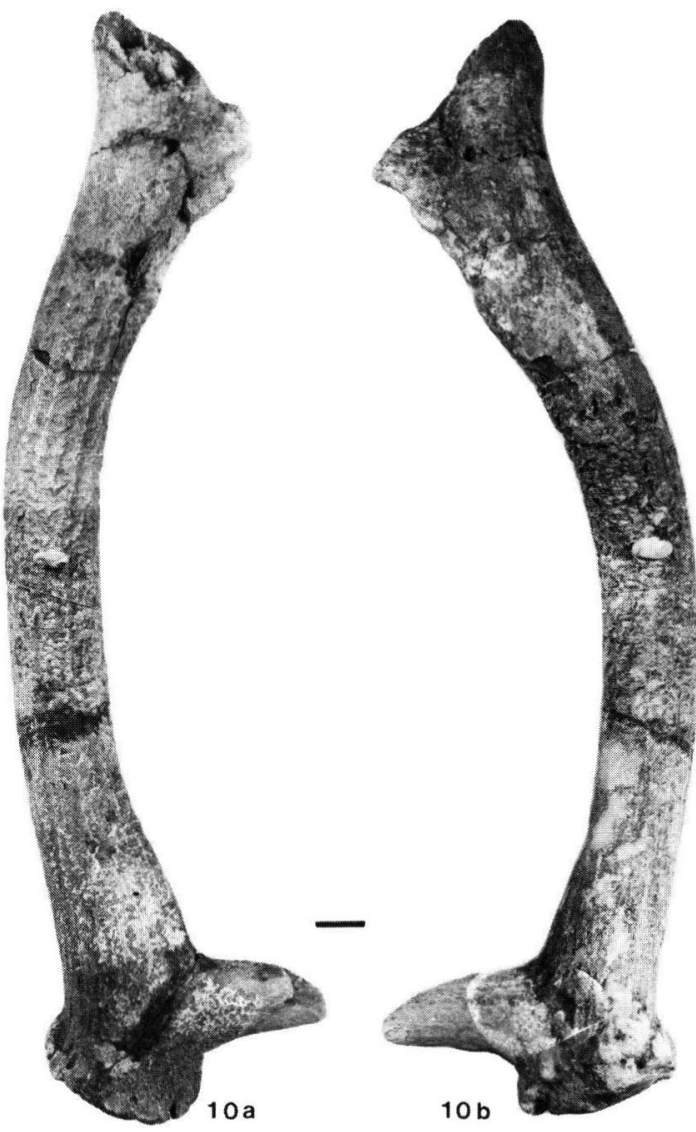

Fig. 10: Antler of Cervus sivalensis (VPL/B 3004). $a$ is mesial and $b$ is lateral view. Bar represents $2 \mathrm{~cm}$.

Abb. 10: Geweihstange von Cervus sivalensis. a zeigt die mesiale und $b$ die laterale Seitenanschicht. Maßstab $=2 \mathrm{~cm}$.

antler of $R$. simplicidens shows a backward bending whereas it is curved outward in C. punjabiensis.

\subsubsection{Cervus sivalensis, LYDEKKER 1880 (Fig. 10)}

1880 Cervus sivalensis LYDEKKER, Pal. Ind. 10, pl. 8, fig. 5

1926 Cervus sivalensis LYDEKKER, Brown, Amer. Mus. Novit. 242

1929 Cervus sivalensis LYDEKKER, Matthew, Bull. Amer. Mus. Nat. Hist. 56, 444

Type: G.S.I. No. B215, a ramus with M2 and M3. Specimens in Amer. Mus. No. 19807, an antler; No. 19829, a skull.

Referred material: VPL/B 3004, a left antler; VPL/B 3005-3015, broken parts of antlers. 
Locality and horizon: Romushi section, 5th horizon in Fig. 2.

\subsubsection{Description of new material}

Left antler with pedicle (VPL/B 3004): The antler is heavily built, rough and supported on a rather long and nearly circular outlined pedicle. The anterior tine projects forward and slightly outward. Posteriorly, the palmate central portion of the antler is continued in beam with median axis and finally it terminates in two points or tines, at which the present is broken. Thus the antler might be said to have a long anteroposterior axis with a single outwardly directed brow tine at the front and a broad double pointed posterior termination. The brow tine of this specimen is broken at its free end at a small distance from the central portion of antler. It curves slightly outward and forward away from the beam and is roughly oval in cross section. The brow tine arises immediately above the burr and makes an obtuse angle (122 degree) with the beam which is slender, nearly oval in cross section, curved laterally along median axis showing the longitudinal grooves on its surface. The prominent longitudinal grooves run parallel to the median axis of beam.

The cervid antler has a branched structure consisting of anterior and posterior prongs which are designated by POCOCK (1933) as "a" (anterior) and "p" (posterior) prongs. According to PoCOCK (1933), as the "p" prong branches more, progressively more complex antlers are found. The anterior prong "a" rarely branches as it projects out over the eye. COLBERT (1936) proposed to call the single anterior tine "a" supposing it to be homologous with "a" tine in other cervids. The backward projecting broad portion (beam) is designated by COLBERT (1936) as "p" and when this part of antler shows two terminal prongs, these are designated as $\mathrm{p}^{\mathrm{e}}$ and $\mathrm{p}^{\mathrm{m}}$ (external and median posterior tines). Following Pocock (1933), the present specimen can be said to have a base with a 1 and $\mathrm{p} 1$ in the primary fork and only one $\mathrm{p} 2$ in secondary fork.

Remarks: $C$. sivalensis antler is shaped very much like of $C$. duvauceli, that is, there is a brow tine directly above burr, while further up the beam divides into two branches, a smaller inner one and larger outer one. C. sivalensis antler is larger than that of Rucervus simplicidens. It is further distinct from $C$. punjabiensis by the development of brow tine immediately above burr and by having the comparatively more rough surface. Siwalik Hills have yielded a number of species of deer (LYDEKKER 1876; PILGRIM 1913; BROWN 1926; MATTHEW 1929; COLBERT 1935; AZZAROLI 1954; GAUR 1981) used in this work for comparison.

\subsection{Proboscidea}

\subsubsection{Elephas hysudricus FALCONER \& CAUTLEY 1845} (Figs. 11-14)

1845 Elephas bysudricus FALCONER \& CAUTLEY, Fauna Antiqua Sivalensis, pl. 1, fig. 3; pl. $4-5$; pl. 6, figs. $1-3$; pl. 7 ; pl. 8, figs. 1 , 3-4; pl. 12B, fig. 4

1884 Elephas meridionalis POHLIG, Sitzung Niederrhein Gesellschaft, Bonn, 47-61

1942 Hypselephas hysudricus FALCONER \& CAUTLEY, Osborn, Proboscidea. 2, figs. 1198-1203, 1206, 1210-1215

1973 Elephas bysudricus FALCONER \& CAUTLEY, Maglio, Trans. Amer. Phil. Soc. 63, pl. 13, p. $48-49$.

Lectotype: Maxillary molar, Fauna Antiqua Sivalensis, pl. 8 (3a).

Table 2: Comparative measurements (in $\mathrm{mm}$ ) of antlers of $C$. punjabiensis and $C$. sivalensis ( $\mathrm{MAX}=$ maximum $; \mathrm{APD}=$ anteroposterior diameter $; \mathrm{CFE}=$ circumference $)$

VPL/B number

MAX APD of preserved portion

APD above burr

Transverse diameter above burr

CFE of beam above burr

CFE of beam at posterior double pointed termination

CFE of brow tine above burr

CFE of brow tine at termination

Angle of brow tine with beam

\section{C. punjabiensis}

3003

325.0

79.5

58.5

181.0

-

131.0

27.0

147
C. sivalensis

3004

462.0

66.0

63.5

161.5

224.0

118.0

93.0

122 

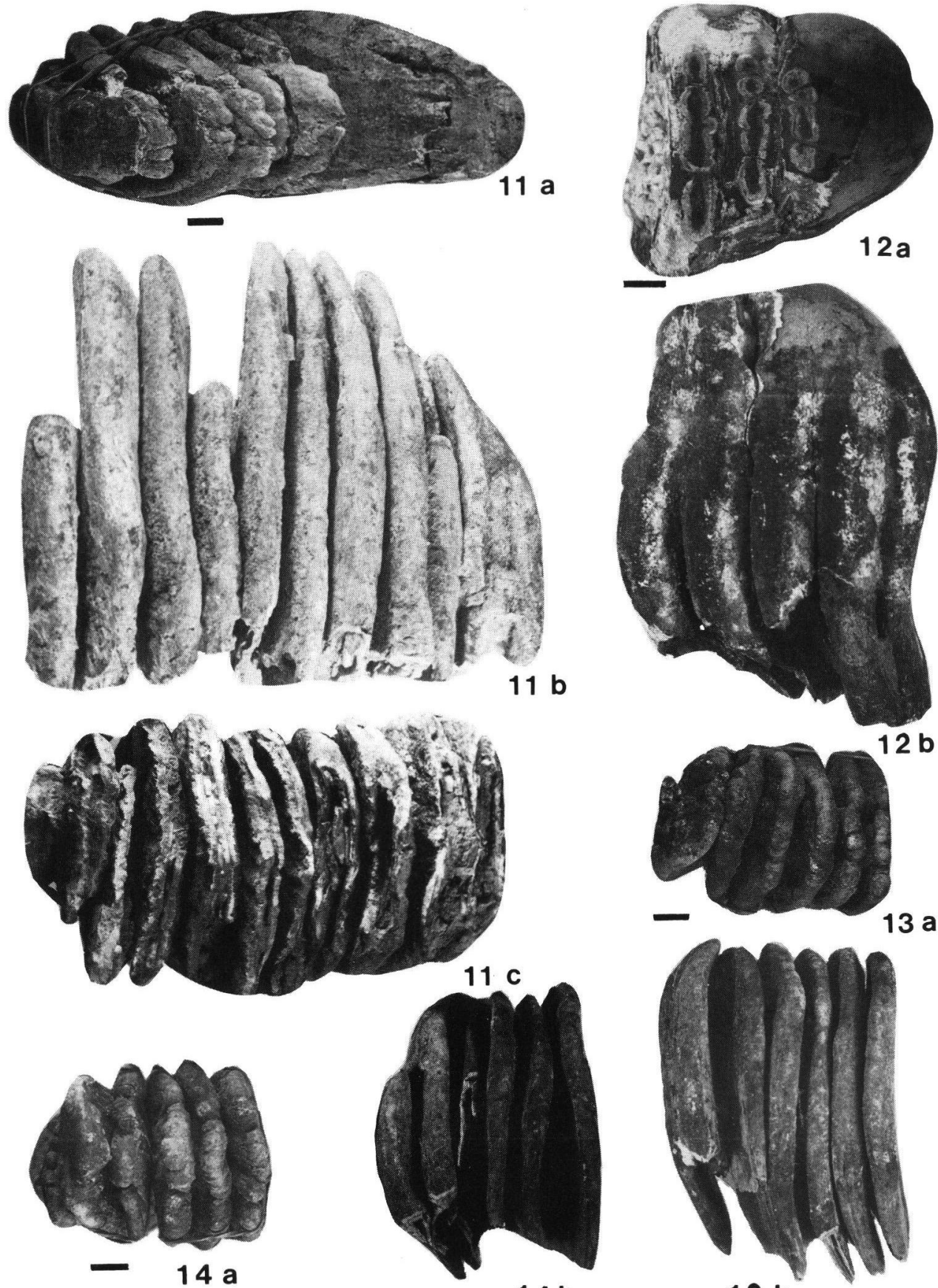

$11 \mathrm{~b}$

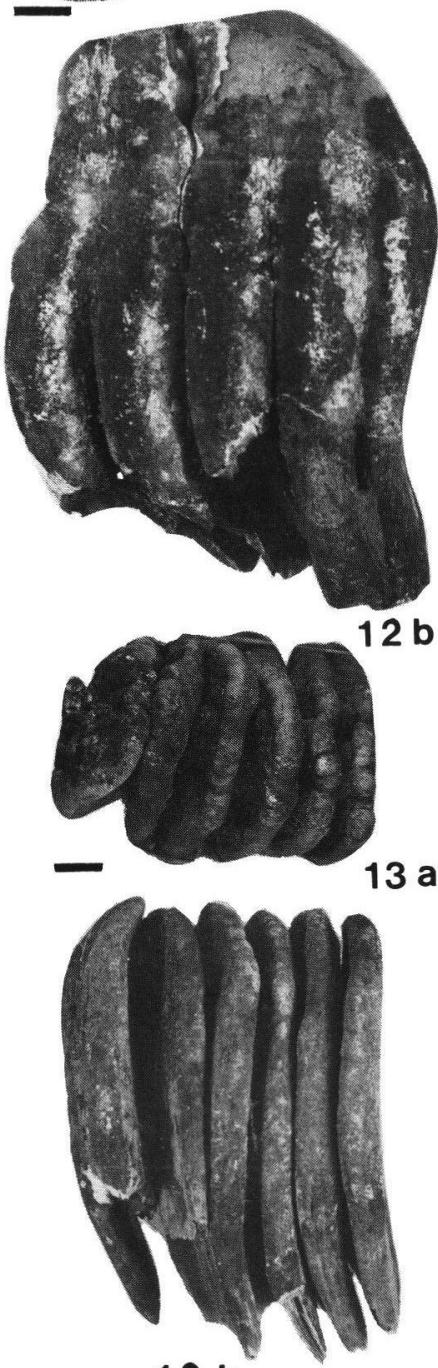

$14 \mathrm{~b}$

$13 \mathrm{~b}$

Fig. 11-14: Molars of Elephas hysudricus from Romushi (14, VPL/B 2063) and from Sombur (11, VPL/B 2061; 12 , VPL/B 2060; 13, VPL/B 2062). 11a, b and c are occlusal, lingual and basal views.

In other figures, $\mathrm{a}$ and $\mathrm{b}$ are occlusal and lateral views. Bar represents $1 \mathrm{~cm}$.

Abb. 11-14: Molarenfragmente von Elephas hysudricus von Romushi und Sombur. 11a, b und c zeigen den Zahn von der Kaufläche, von lingual und von der Unterseite. In den anderen Abb. zeigt a die Kauflächen und b die laterale Seite. $\mathrm{Maßstab}=1 \mathrm{~cm}$. 
Hypodigm: Numerous specimens as described by FALCONER \& CAUTLEY (1845-1846) and Osborn (1942). Housed mainly in British Museum Natural History, Indian Museum \& Amer. Mus. of National History.

Referred material: VPL/B 2060 to VPL/B 2063, all broken molars; Several incomplete teeth together with other skeletal remains.

Locality and horizon: VPL/B 2063 is from Romushi section (6th horizon). Others are from Sombur ( 7 th horizon). See Fig. 2.

\subsubsection{Description of the new material}

VPL/B 2060: The molar is broken posteriorly to about sixth plate. It is in advanced stage of wear and all the conelets are sufficiently worn to form a plate. The anteriormost plate, on the lingual side, consists of two compressed and relatively small conelets. The second plate comprises of five conelets, the third and fourth from lingual side are fused. There are four distinct enamel islands present in the second plate. The third plate consists of four broad conelets in which third and fourth conelets are fused to form three individual lamellae. The enamel is smooth, thin and highly plicated. Plications are abundant in central part along the anteroposterior axis of tooth. The maximum thickness of enamel is $2.5 \mathrm{~mm}$. The valleys in between the plates are wide, open and filled with cement. The length and height of the preserved portion of tooth are 75.0 and $70.0 \mathrm{~mm}$ respectively.

VPL/B 2061: The molar possesses at least eleven plates and is relatively the best preserved. Three anteriormost plates are joined together and the first four plates from anterior show the sign of abrasion. The surface of wear of all plates which are embedded in cement is concave. The ridges are unworn showing characteristic folded and plicated enamel. The enamel is smooth, thin and plicated and thickness ranges from $2.5 \mathrm{~mm}$ to $2.8 \mathrm{~mm}$. The length and height of preserved portion are 140.5 and $147.0 \mathrm{~mm}$ respectively.

VPL/B 2062: This broken tooth has six to seven ridge plates. Anteriormost plate is much smaller than second and is broken posteriorly. The second plate is slightly bent downwards and therefore leaves much place between the second and third. All plates are unworn and embedded in cement. Maximum enamel thickness is $2.8 \mathrm{~mm}$. Molar shows slight expansion towards posterior side. In lateral view, the unworn ridge plates are extended straight on the occlusal surface except second and third plates which are bent upward in the opposite directions.
VPL/B 2063: The molar, broken posteriorly, consists of six ridge plates, the anterior most being smaller than second. The plates are unworn and show folded enamel. The maximum thickness of enamel reaches up to $2.7 \mathrm{~mm}$ and in general is highly variable from anterior to posterior portion of teeth.

Remarks: The two most important and approximately similar aged species of Indian Elephas, E. hysudricus and E. (Archidiskodon) planifrons can be distinguished by: thickness of enamel (comparatively more in E. planifrons); shape of molars (very broad in $E$. planifrons); and the ratio of crown height to width of molar (greater in E. hysudricus). E. hysudricus is also distinct from $E$. planifrons in lacking the median expansion in the plates and in marking by strong plications in the enamel. The third species, E. platycephalus, reported by OSBORN (1929), however has a questionable relationship and may represent one stage of $E$. planifrons (MAGLIO 1973). The fourth species, $E$. namadicus, is younger than first two species, and is distinct from them in having low enamel thickness in teeth as well as a very high crown height, upto 150 percent greater than the width (MAGLIO 1973).

E. bysudricus has been reported by various workers from India and nearby regions; from Java (DuBOIS 1908, HOOIJER 1952, KOENIGSWALD, 1935, 1956), from Burma (COLBERT 1943), from the Indian Siwaliks (FAlCONER \& Cautley 1845, HoOijer 1955, NANDA 1976, GAUR 1981), from Narmada and Godavari Valleys (FALCONER \& CAUTLEY 1845, BADAM 1979), and from Karewas (DE TERRA \& PATERSON 1939, BADAM 1968, 1979; KOTLIA 1985 b). And based on this find, the Trinil and Djetis beds of Java are correlated with Narmada beds of Central India and Pinjors of Siwaliks respectively (KOENIGSWALD 1935, 1956). Similarly, the Irrawaddy fauna of Burma is considered to be extension of Upper Siwalik fauna (COLBERT 1943). E. bysudricus with other mammalian assemblages is also considered as the index fossil for the Middle Pleistocene (BADAM 1979).

\subsection{Carnivora}

\subsubsection{Canis vitastensis KOTLIA 1987}

Holotype: VPL/B 3001, a left lower mandibular ramus with second molar, described in detail by KOTLIA (1987b).

Locality and horizon: Burzahom section, 8th horizon.

\subsubsection{Brief description of material}

The ramus is slender exhibiting a prominent sigmoid curve on the lingual side. The paraconid on M2 is 
developed and metaconid is the largest cusp on the tooth. Protoconid is high, hypoconid poorly developed, entoconid lower than hypoconid, talonid triangular and shallow basined, trigonid smaller than talonid, and the external and internal cingula are well developed. The ratio of independent lengths of $\mathrm{M} 1$, $\mathrm{M} 2$ and $\mathrm{M} 3$ of this specimen (in case of $\mathrm{M} 1$ and $\mathrm{M} 3$, diameters of alveoli have been taken) is far from members of subfamily Amphicyoninae. The specimen has been easily distinguished from other species of Canis, i.e., C. curvipalatus and C. cautleyi, reported by PILGRIM (1932) from Upper Siwaliks, in having a better anterior cingulum in form of paraconid and a rounded entoconid which is higher than ridge shaped hypoconid (KotLIA 1987b). Further the talonid on lower second molar of $C$. cautleyi consists of a trenchant hypoconid and a small entoconid whereas the talonid on this tooth of $C$. vitastensis is triangular in outline.

According to KotLia (1987b), the ratio of length and width of the lower molars in fossil and living species of Indian Canis varies from 0.417 to 0.6 (M 1); from 0.667 to 0.706 (M2) and from 0.7 to 0.737 (M3), which fall within the limit of $C$. vitastensis with ratio of 0.46 (M 1); of 0.667 (M 2) and of 0.7 (M3).

\section{Stratigraphic occurrence of the fossils}

While discussing the placement of the fossil mammals with respect to magnetic polarity time scale for Karewas, it is noted that the appearances of Equus, Cervus and Elephas in Kashmir are later than in the Siwaliks of Indian subcontinent.

E qu id a e : The oldest occurrence of Equus in North America is dated to $3.5 \mathrm{Ma}$ (EVERNDEN et al. 1964). BOUT (1970) proposed an age of $2.5 \mathrm{Ma}$ for the oldest appearance of Equus in the Old World (in Perrier faunas of Auvergne-Velay areas). KELLER et al. (1977) initially based their palaeomagnetic data on the supposed oldest occurrence of Equus at about
1.8 $\mathrm{Ma}$ in Pakistan. Subsequently, OPDYKE et al. (1979) recorded earliest appearance of Equus at $2.48 \mathrm{Ma}$ in northern Pakistan. This was confirmed as the oldest appearance of Equus in southern Asia by BARRY et al. (1982). AZZAROLI \& NEPOLEONE (1982) recorded Equus in the Indian Siwaliks from the Matuyama magnetic epoch whereas, TANDON et al. (1984) discussed the appearance of Equus at about Gauss / Matuyama boundary (2.48 Ma). More recently, RANGA RAO et al. (1988) described Equus remains in Jammu Siwaliks from a level, $61 \mathrm{~m}$ below this boundary. The present study records the oldest appearance of Equus in Romushi section from Matuyama magnetic epoch (roughly at Reunion event) and in Kilar section from the top of Olduvai event (1.6 Ma), marking 3rd and 4 th horizons respectively (Fig. 2). The horizon exposed along River Shaliganga at site Husgund (Raithan) and yielding Equus remains is correlated with the 3rd horizon of Romushi section (KOTLIA et al. 1982; KUSUMGAR et al. 1986).

C e r vida e : OPDYKE et al. (1979) recognized lowest occurrence of cervid with antlers in upper Gauss epoch. AZZAROLI \& NAPOLEONE (1982) reported Cervus antlers from Matuyama epoch. RANGA RAO et al. (1988) listed Cervus antlers in Jammu fauna from slightly below Gauss/Matuyama boundary. $C$. punjabiensis antlers, in this work, are recorded from Matuyama magnetic epoch, roughly at Reunion event (2nd horizon), and C. sivalensis is reported from upper part of Olduvai event (5th horizon).

E l e p h a n t i d a e: The lowermost record of Elephas (Archidiskodon) in Pakistan Siwaliks according to OPDYKE et al. (1979) is just above Kaena event $(2.9 \mathrm{Ma})$. It is reported from Matuyama epoch in the Indian Siwaliks (AzZAROLI \& NAPOLEONE 1982). In Jammu Siwaliks, RANGA RAO (1988, Fig. 6) reports Archidiskodon from Gilbert epoch and Elephas from Matuyama epoch. The record of $E$. (Archidiskodon) planifrons from Gilbert epoch may be rather surprising. RANGA RAO et al. (1988) have further discussed, probably in the same area, the

Table 3: Variation in the comparative measurements of M 1, M 2 and M 3 of Indian canids (After KOTLIA 1987b)

\begin{tabular}{|c|c|c|c|c|}
\hline Genus and species & length & length & length & ratios \\
\hline & M 1 & M2 & M3 & \\
\hline
\end{tabular}

\begin{tabular}{|c|c|c|c|c|}
\hline Amphicyon pitbicopbilus & 31.0 & 23.1 & 16.0 & $1: 0.75: 0.52$ \\
\hline A. palaeindicus & 31.0 & 21.7 & 13.0 & $1: 0.70: 0.42$ \\
\hline Canis cautleyi & 24.0 & 10.0 & 4.8 & $1: 0.42: 0.20$ \\
\hline C. vitastensis & 18.5 & 9.0 & 4.0 & $1: 0.49: 0.22$ \\
\hline C. familiaris & 20.0 & 8.5 & 3.8 & $1: 0.43: 0.20$ \\
\hline
\end{tabular}


appearance of Archidiskodon at about Gauss/ Matuyama boundary. E. hysudricus in Karewas is recorded only after $0.73 \mathrm{Ma}$ from Romushi section (6th horizon) and Sombur (7th horizon).

$\mathrm{H}$ i p p o p o t a m i d a e: Hexaprotodon in Pakistan is from lowermost Gauss epoch (OPDYKE et al. 1979). It is recorded in the Jammu Siwaliks from Gilbert and Matuyama chrons (RANGA RAO et al. 1988). In Kashmir, Hexaprotodon is recovered only from locality Dubjan (1st horizon) from the normally magnetised sediments that may be considered to fall in the Gilbert epoch, probably Cochiti event.

C a n i d a e : OPDYKE et al. (1979) have reported Canis from Matuyama epoch. In this work, it is described from the Burzahom section (Upper Karewas) which is younger than $730 \mathrm{Ka}$ and older than $200 \mathrm{Ka}$ (AgRAWAL et al. 1987. The locality is marked as 8th horizon.

The Lower Karewa deposits have yielded a greater number of specimens than the Upper Karewa deposits. This disparity in the proportions could be attributed to greater thickness and better exposed nature of former. Among megavertebrates, Equus, Elephas and Cervus are better represented. As compared with Tatror and Pinjor Formations of nearby Siwaliks where one third of mammalian assemblage consists of bovids, the present assemblage is devoid of bovids. Even in literature, only a couple of bovid specimens (DE TERRA \& PATERSON 1939, BADAM 1972) have been documented in the past. Also, the absence of crocodilids and chelonids which are so abundant in the Tatrot and Pinjor Faunas probably indicates that the climate during Karewa deposition was probably colder than that of Upper Siwaliks. It is well known that the reptiles attain profusion and great size only in the warmer climates. Besides, KotLIA (1989) described 15 fossiliferous horizons of the cyprinid fishes, mainly from the Lower Karewa localities. Among the micromammals, a number of specimens belonging to arvicolids, murids and soricids from three levels (2.5, 1.6 and $<730 \mathrm{Ka}$ in age) have been collected. Some of the results on arvicolids, aged $1.6 \mathrm{Ma}$, are published (Kotlia 1985a), and the detailed studies are in progress. In addition to vertebrates, numerous specimens of gastropodes and ostracodes have also been sampled.

The greater frequency of grazing forms such as horses and elephants probably suggests the presence of enough grass covered areas to support large herds of these animals. The occurrence of enough browse alongwith grasses is indicated by cervids. The high proportional percentage of antlers compared to teeth is probably artificial as a single antler can break down into a number of fragments. The habitat spectra of Karewa mammals suggest a mosaic of dominant grass- land and wooded grassland with subordinate woodland and some bushland (KOTLIA 1985 b). It appears that the areas close to the ancient lake were more open and supported grassy vegetation with some tree and bush cover.

\section{Pliocene-Pleistocene boundary}

The delineation of Plio-Pleistocene boundary has drawn the attention of workers for well over a century. The boundary has been placed in the light of various interpretations comparing the various data available on Siwalik vertebrate palaeontology and glacial sequences, at the base of Tatrot (MATTHEW 1929; LEWIS 1937; DE TERRA \& PATERSON 1939; HoOIJER 1955), at the base of Pinjor (SAHNI \& KHAN 1964; NANDA 1976) and the base of Boulder Conglomerate (PILGRIM 1944; WAdia 1951; SATSANGI \& DutTA 1971). However, with the advent of magnetic polarity time scale in the Siwaliks, various workers (OPDYKE et al. 1979; AZZAROLI \& NAPOLEONE 1982; TANDON et al. 1984; RANGA RAO et al. 1988) came to an agreement that the Tatrot/Pinjor boundary be equated with the Gauss/Matuyama boundary (2.48 Ma). Most of these workers also agreed that the earliest appearance of Equus coincides with this boundary. The author is in agreement with the view that Tatrot/Pinjor boundary coincides with the Gauss/Matuyama boundary and that the Equus arrived in the subcontinent approximately at this time. The Plio-Pleistocene boundary in Siwaliks has been approximated at Olduvai event (KELLER et al. 1977; FLYNN \& JACOBS 1982; KUSUMGAR et al. 1986), and either at top of Olduvai event or at Gauss/Matuyama boundary (RANGA RAO 1988; RANGA RAO et al. 1988).

OPDYKE et al. (1979) listed a number of fauna: Canis, Mustela, Hyaena, Felis and Machairodus etc., all appearing immediately above Olduvai event. Approximately at the Olduvai event, the appearance of some micromammals (Mus, Golunda, cf. Rattus) is shown by FLYNN \& JACOBS (1982) who consider this level as biostratigraphically very important. KOTLIA (1985a) described from the Olduvai event the arvicolids which are considered to be useful biochronological markers for Plio-Pleistocene. KoTLIA (1989) surveyed the Karewas also for fish remains and found that just a single horizon yielded fossil fishes after Olduvai event compared to fourteen horizons below this level. The combined data on mega and microvertebrate palaeontology therefore suggest that a major global fauna change occurred at about Olduvai event.

How did the climate play a role in the Kashmir Valley and elsewhere at Gauss/Matuyama boundary and at Olduvai event? The oldest appearance of arvicolids 
which serve as control points in Holarctic history, in Kashmir is now dated to about $2.5 \mathrm{Ma}$ (KotLiA 1987a). The arvicolid level described as marking the N/Q boundary (KUSUMGAR et al. 1986) now becomes the second appearance of arvicolids in Kashmir. The Karewa arvicolid biochronology therefore starts from about 2.5 Ma (Gauss/Matuyama boundary) which is close to age of first significant glaciation in northern Hemisphere (REPENNING 1983). Based on pollen data, this period in Kashmir is characterised by progressive cooling (AGRAWAL et al. 1987). When we compare with global data, SHACKLETON et al. (1984) have also shown the evidence of glaciation at this time. The climatic pattern at Olduvai period in Kashmir is worked out by KRISHNAMURTHY et al. (1986) by showing at this period a prominent cold climate. The occurrence of arvicolids (KOTLIA 1985a) also confirms cold climatic phase at this age. It may be mentioned here that in Kashmir from 4.0 to $1.8 \mathrm{Ma}$, the conglomerates were derived from northeast and were shed down after mid-Olduvai time from south and southwest margin of the basin (BURBANK \& JOHNSON 1983). In ocean cores studies, this period is characterised by major cold water, high salinity and seasonality peaks (HAQ et al. 1977). This palaeooceanic feature is equated with first major glacial advance in North America (BERGGREN \& VAN COUVERING 1974).

The author opines that the Equus is pre-Pleistocene. The appearance of Equus and Cervus with antlers so far in the Karewas is later than Siwaliks. The PlioPleistocene boundary in Kashmir intermontane basin lies at Olduvai event coinciding with cold (glacial) period (KRISHNAMURTHY et al. 1986), and the occurrence of Holarctic elements (arvicolids). This event may be correlated with the observation of BURBANK \& JoHNSON (1983) in Kashmir as the enhanced tectonic activity along Main Boundary Thrust Complex that was precursor the major upliftment in Pir Panjal Range and to subsequent cessation of widespread intermontane sedimentation at about $1.7 \mathrm{Ma}$. In Siwaliks, following PILGRIM (1944) and SATSANGI \& DUTTA (1971), the boundary may correlate with a stage of commencement of Boulder Conglomerate deposition which according to RANGA RAO (1988) took place at about $1.7 \mathrm{Ma}$. All these dates are very close to the revised Neogene/Quaternary boundary $(1.6 \mathrm{Ma})$ which according to HAQ et al. (1977) is coeval with the earliest climatic deterioration in the Pleistocene.

\section{Acknowledgements}

Field work was done under Kashmir project of Govt. of India. Prof. A. SAHNI, Chandigarh provided useful literature. Magnetostratigraphy was carried out with
Drs. D. P. Agrawal and S. Kusumgar of P.R. L. Ahmedabad, India. Prof. W. vON KoENIGSWALD, Paläontologisches Institut, Bonn, provided work facilities, went through manuscript very critically and suggested some modifications in text. The Alexander von Humboldt Stiftung, Bonn, West Germany provided the financial assistance in form of an excellent research fellowship.

\section{References}

Agrawal, D. P., Kotlia, B. S., Kusumgar, S. \& Gupta, S. K. (1987): Quaternary palaeoenvironmental changes in northwest India. - In: SAHNI, A. \& GAUR, R. (Ed.): Perspectives in Human Evolution, Renaissance: 223-260; New Delhi.

Azzaroli, A. (1954): Critical observations upon Siwalik deer. - Proc. Linn. Soc. London, 165: 75-83; London.

- (1979): On a Late Pliocene Ass from Tuscany, with notes on history of Asses. - Paleontogr. Italica, 71: 27-47; Pisa.

- \& Napoleone, G. (1982): Magnetostratigraphic investigation of the Upper Siwaliks near Pinjor, India. - Riv. Ital. Paleont. Stratigr., 87 (4): 739-762; Milano.

BADAM, G. L. (1968): Note on the occurrence of fossil vertebrates in the Karewas of Kashmir. - Res. Bull. Panjab Univ., 19 (3-4): 453-455; Chandigarh.

- (1972): Additional mammalian fossils in the Karewas of Kashmir. - Curr. Sci., 41 (4): 529-530; Bangalore.

- (1979): Pleistocene Fauna of India. - Pune (Deccan College, India).

BARry, J. C., Lindsay, E. H. \& JacobS, L. L. (1982): A biostratigraphic zonation of the Middle and Upper Siwaliks of Potwar Plateau of northern Pakistan. - Palaeogeogr. Palaeoclimatol. Palaeoecol., 37: 95-130; Amsterdam.

Berggren, W. A. \& van Couvering, J. A. (1974): The Late Neogene biostratigraphy, geochronology and palaeoclimatology of the last 15 million years in marine and continental sequences. - Palaeogeogr. Palaeoclimatol. Palaeoecol., 16 (1-2): 1-216; Amsterdam.

Bнатт, D. K. (1975): On the Quaternary geology of Kashmir with special reference to stratigraphy and sedimentation. - Misc. Publ. Geol. Surv. India, 24 (1): 188-203; Calcutta.

- (1983): Karewa lake in Kashmir: Its extent genesis and modification. - Cont. Geo. Res. Him., 2: 99-104; Dehradun.

Bout, P. (1970): Absolute ages of some volcanic formations in the Auvergne and Velay areas and chronology of the European Pleistocene. - Paleogeogr. Palaeoclimatol. Palaeoecol., 8: 95; Amsterdam.

Brown, B. (1926): A new deer from the Siwaliks. - Amer. Mus. Novitat., 242: 1-11; New York. 
Burbank, D. W. \& Johnson, G. D. (1982): Intermontane basin development in the past $4 \mathrm{Myr}$. in the northwest Himalaya. - Nature, 298: 432-436; London.

- \& - (1983): The Late Cenozoic chronologic and stratigraphic development of the Kashmir intermontane basin, north-western Himalayas. - Palaeogeogr. Palaeoclimatol. Palaeoecol., 43: 205-235; Amsterdam.

Colbert, E. H. (1935): Siwalik mammals in the American Museum of Natural History. - Trans. Amer. Phil. Soc., 26: 1-385; Philadelphia

- (1936): Tertiary deer discovered by the American Museum Asiatic Expedition. - Amer. Mus. Novitat., 485: 1-21; New York.

- (1943): Pleistocene vertebrates collected in Burma by the American Southwest Asiatic Expedition. - Trans. Amer. Phil. Soc., 32 (3): 395-429; Philadelphia.

de Terra, H. \& Paterson, T. T. (1939): Studies on Ice Age in India and Associated Human Cultures. - Carnegie Institution, Washington, 493: 1-453; Washington D. C.

Dubois, E. (1908): Das Geologische Alter der Kendeng oder Trinil fauna. - Tijdschr. Neder. Aardr. Genoots. Ser., 2 (25): 1235-1270; Amsterdam.

Evernden, J. F., Savage, D. F., Curtis, G. H. \& James, G. T. (1964): Potassium-argon dates and the Cenozoic mammalian and chronology of North America. Amer. Jour. Sci., 262: 145-198; New Haven.

Falconer, H. \& Cautley, P. T. (1945-1949): Fauna Antiqua Sivalensis - Being the fossil Zoology of Siwalik Hills in the North India. - Part I, 1946; Part II, 1947; Part III-VIII, 1949. London (Smith Elder \& Co.).

FLYNN, L. J. \& JACOBS, L. L. (1982): Effects of changing environments on Siwalik rodent faunas of northern Pakistan. - Palaeogeogr. Palaeoclimatol. Palaeoecol., 38: 129-138; Amsterdam.

Gaur, R. (1981): Palaeontology and palaeoecology of PlioPleistocene Upper Siwalik sediments in the NE Chandiarh. - Thesis, Anthr. Deptt. Panjab Univ.: 1-322; Chandigarh. - [Unpubl.].

Haq, B. U., Berggren, W. A. \& van Couvering, J. A. (1977): Corrected age of the Pliocene-Pleistocene boundary. - Nature, 269: 483-488; London.

HoojJer, D. A. (1952): Fossil mammals and Plio-Pleistocene boundary in Java. - Proc. Konin. Neder. Akad. Wetensch. 55 (4): 436-443; Amsterdam.

- (1955): Archidiskodon planifrons (Falconer \& Cautley) from the Tatrot Zone of the Upper Siwaliks. - Leidse Geol. Meded., 20: 110-119; Leiden.

Keller, H. M., Tahirkheli, R. A. K., Mirza, M. A., JohnSON, G. D., JOHNSON, M. N. \& OPDYKe, N. D. (1977): Magnetic polarity stratigraphy of the Upper Siwalik deposits, Pabbi Hills, Pakistan. - Earth Planet. Sci. Lett., 36: 187-201; Amsterdam.
KHAN, E. (1972): Narmada alluviam and its equivalents. Proc. Ind. Natn. Sci. Acad., 38 (3-4): 89-96; New Delhi.

Koenigswald, G. H. R. von (1935): Die fossilen Säugetierfaunen Javas. - Proc. Konin. Neder. Akad. Wetensch., 38: 188-198; Amsterdam.

- (1956): Remarks on the correlation of mammalian faunas of Java and India and the Plio-Pleistocene boundary. - Proc. Konin. Neder. Akad. Wetensch., 59 (3): 204-210; Amsterdam.

KotliA, B. S. (1985a): Quaternary rodent fauna of the Kashmir Valley, NW India; Systematics, biochronology and palaeoecology. - Jour. Paleontol. Soc. India, 30: 81-91; Lucknow.

- (1985b): Vertebrate fossils and palaeoenvironments of the Karewa intermontane basin, Kashmir, NW India. Current Sci., 54: 1275-1277; Bangalore.

- (1987a): Discovery of fossil arvicolids in Indian subcontinent from Kashmir basin: Systematics and biochronology. - Publ. Geol. Surv. Czechoslovakia, Praha. [In press].

- (1987b): A new species of canis from the Kashmir intermontane basin, India. - Jour. Paleontol. Soc. India, 32: Lucknow. - [In press].

- (1989): Plio-Pleistocene fossil fish remains from Kashmir Valley, NW India: Biochronology, systematics and palaeoecology. - Jour. Paleontol. Soc. India, 34: Lucknow. - [In press].

-, Sahni, A., Agrarwal, D. P. \& Pant, R. K. (1982): New vertebrate evidence for the age of Karewa sediments, Kashmir. - Man \& Environment, 6: 13-15; Pune.

Krishnamurthy, R. V., Bhattacharya, S. K. \& Kusumgar, S. (1986): Palaeoclimatic changes deduced from $13 \mathrm{C} / 12 \mathrm{C}$ and $\mathrm{C} / \mathrm{N}$ ratios of Karewa lake sediments, India. - Nature, 323: 150-152; London.

Kusumgar, S. (1980): Geochronology and palaeoclimatic events on the Late Cenozoic periods in the Kashmir Valley. - Thesis, Bombay Univ.: 1-191; Bombay. [Unpubl.].

-, Agrawal, D. P. \& Kotlia, B. S. (1985): Magnetic statigraphy of the Karewas of the Kashmir Valley. - In: Current Trends in Geology, 6: 13-17; New Delhi.

-, Kotlia, B. S., Agrawal, D. P. \& Sahni, A. (1986): Biochronologie des fossiles de vertebres des formations des Karewas du Cachemire, Inde. - L'Anthropologie, 90 (2): 151-164; Paris.

LEWIS, E. G. (1937): A new Siwalik correlation. - Amer. Jour. Sci., 5 (33): 191-204; New Haven.

LYDEKKER, R. (1876): Notes on the fossil mammalian faunas of India \& Burma. - Rec. Geol. Surv. India, 9: 86-106; Calcutta.

Maglio, V. J. (1973): Origin and evolution of Elephantidae. - Trans. Amer. Phil. Soc., 63 (3): 1-149; Philadelphia. 
MATTHEW, W. D. (1929): Critical observations upon Siwalik mammals. - Bull. Amer. Mus. Nat. Hist., 56 (7): 437-560; New York.

Middlemiss, C. S. (1924): Lignite coal beds in the Karewa Formation of Kashmir Valley. - Rec. Geol. Surv. India, 55 (3): 241-250; Calcutta.

NANDA, A. C. (1976): Some proboscidean fossils from the Upper Siwalik sub-group of Ambala. - Him. Geol., 6: 1-26; Dehradun.

Opdyke, N. D., Johnson, G. D., Johnson, M. N., TAHIRKHELI, R. A. K. \& MIRZA, M. A. (1979): Magnetic polarity stratigraphy and vertebrate palaeontology of the Upper Siwalik sub-group of northern Pakistan. - Palaeogeogr. Palaeoclimatol. Palaeoecol., 27: 1-34; Amsterdam.

OsBorn, H. F. (1929): New Eurasiastic and American proboscideans. - Amer. Mus. Novitat., 393: 1-22; New York.

PILGRIM, G. E. (1913): Correlations of the Siwaliks with mammal horizons of Europe. - Rec. Geol. Surv. India, 43 (4): 264-326; Calcutta.

- (1932): The fossil carnivora of India. - Paleont. Indica, 18: $1-232$; Calcutta.

- (1944): The lower limit of the Pleistocene in Europe and Asia. - Geol. Mag., 81: 28-38; London.

Pocock, R. I. (1933): The homologies between the branches of the antlers of the Cervidae based on the theory of dichotomous growth. - Proc. Zool. Soc. London: 377-406; London.

RANGA RAO, A. (1988): Neogene-Quaternatry in Siwaliks of the northwest Himalayan foothills. - Proc. Stratigr. Boundary Probl. India, April, 7-9, 1988: 58-72; Jammu.

-, Agrawal, R. P., Sharma, U. N., Bhalla, M. S. \& NANDA, A. C. (1988): Magnetic polarity stratigraphy and vertebrate palaeontology of the Upper Siwalik subgroup of Jammu Hills, India. - Jour. Geol. Soc. India, 31: 361-385; Bangalore.

REPENNING, C. A. (1983): Quaternary rodent biochronology and its correlation with climatic and magnetic stratigraphies. - In: MAHANEY, W. C. [ed.]: Correlation of Quaternary Chronologies, Geo Books: 105-118; Toronto.
ROY, D. K. (1975): Stratigraphy and palaeontology of the Karewa Group of Kashmir. - Misc. Publ. Geol. Surv. India, 24: 204-221; Calcutta.

SaHNi, A. \& Kotlia, B. S. (1985): Karewa microvertebrates: Biostratigraphical and palaeoecological implications. - In: Current Trends in Geology, 6: 29-43; New Delhi.

SAHNI, M. R. \& KHAN, A. (1964): Stratigraphy, structure and correlation of the Upper Siwaliks, east of Chandigarh. - Jour. Paleontol. Soc. India, 14: 61-74; Lucknow.

SATSAngi, P. P. \& DutTA, E. (1971): Advances in the stratigraphy of the Siwalik rocks. - Rec. Geol. Surv. India, 101: 193-208; Calcutta.

Shackleton, N. J., Backman, J., Zimmerman, H., Kent, D. V., Hall, M. A., Roberts, D. G., Schnitker, D., Baldauf, J. C., Desprairies, A., Homrighausen, R., Huddlestun, P., Kenne, J. B., Kattenback, A. J., Krumsiek, K. A. O., Morton, A. C., Murray, J. W. \& WeStBURG-SMITH, J. (1984): Oxygen isotope calibration on the onset of ice rafting and history of glaciation in the North Atlantic region. - Nature, 307: 620-623; London.

SINGH, I. B. (1982): Sedimentation pattern in the Karewa basin, Kashmir Valley, India, and its geological significance. - Jour. Paleontol. Soc. India, 27: 71-110; Lucknow.

Tandon, S. K., Kumar, R., Koyama, M. \& Nitsuma, N. (1984): Magnetic polarity stratigraphy of the Upper Siwalik subgroup, east of Chandigarh, Panjab Himalayas, India. - Jour. Geol. Soc. India, 25 (1): 45-55; Bangalore.

TeWari, B. S. \& KaCHROO, P. K. (1977): On the occurrence of Equus sivalensis from Karewas of Shupiyan, Kashmir Valley. - Recent Res. Geol., 3: 468-477; New Delhi.

VISHNU-MITTRE (1964): On the Plio-Pleistocene boundary in northwest India. - Palaeobot., 12 (3): 270-276; Lucknow.

WADIA, D. N. (1951): Plio-Pleistocene boundary in NW India. - Int. Geol. Congr. London (1948), 18: 43-48; London.

Manuscript accepted on 29. 08. 1989 